\title{
RATIFICATION AND CONSEQUENCES OF SEXUAL OFFENSES IN THE CRIMINAL CODE OF GEORGIA
}

\author{
Jumber Mailashvili* \\ Grigol Robakidze University, School of Law, Tbilisi, Georgia, E-mail: jumberlaw@yahoo.com
}

(Received: September 2021; Accepted: November 2021; Published: December 2021)

Abstract: This paper will discuss the issues of qualification of crimes against Sexual Freedom and Inviolability considered by Chapter 22 of Criminal Code of Georgia, which were made in the Criminal Code of Georgia after the Parliament of Georgia ratified the Council of Europe Convention on "preventing and combating violence against women and domestic violence" (Istanbul Convention) adopted on May 11, 2011. Georgia signed this Convention on June 19, 2014. This paper will discuss the relative aspects of qualifying circumstances and disposition of rape and other related corpora delicti and their understanding in a new manner. The article will study the pros and cons that resulted in the fundamental changes made to the Criminal Code of Georgia on May 30, 2018, after the ratification of the "Istanbul Convention". The concept prevailing, in theory, provides a new definition about what problems were solved and what contradictions arose from the new changes. In court practice, there still prevails the view that in order for the action to be assessed as rape, it is necessary for a woman to carry out "selfless" resistance to the offender. However, there are frequent cases when no signs of resistance are found on the victim's body. Given the above, as evidence of the absence of consent is not often established to a high standard by the investigation (for example, in the event of a threat of violence), the case ends with the acquittal of the accused. The article will present recommendations on making changes in some components of the action by the Parliament of Georgia in the future. Based on the scientific literature and the legislation, both, main and additional qualifying elements considered by the disposition of the given Articles will be discussed in detail.

Keywords: CC (Criminal Code); rape, sexual freedom; sexual inviolability; sexual penetration; violence; the threat of violence; abusing a helpless condition of a person affected; force; lewd act.

\section{Introduction}

The research goal of this paper is to discuss the issues of qualification of offenses against sexual freedom and inviolability. After the ratification of the "Istanbul

\footnotetext{
*Corresponding author: Jumber Mailashvili.E-mail: jumberlaw@yahoo.com
}

Copyright (C) 2021 The Author(s). Published by VGWU Press

This is an Open Access article distributed under the terms of the Creative Commons BY 4.0 license (Creative Commons - Attribution 4.0 International - CC BY 4.0) which permits unrestricted use, distribution, and reproduction in any medium, provided the original author and source are credited. 
Convention", the Parliament of Georgia established the disposition of the sections of Chapter 22 of the Criminal Code of Georgia - Offenses against sexual freedom and inviolability - in a new manner. The disposition of Article 137 of the Criminal Code and other sections has undergone significant changes. Prior to the changes made to the Criminal Code of Georgia, rape was defined as a relationship between the opposite sexes, in particular, sexual intercourse through the violation of a woman's sexual freedom and inviolability committed with violence, under the threat of violence or by abusing a helpless condition of a person. The offender was a male. Prior to the amendments to the Criminal Code, the disposition of rape was interpreted as follows: "Rape, that is a sexual intercourse committed with violence, under threat of violence or by abusing a helpless condition of a person affected." After the ratification of the "Istanbul Convention" by the Parliament of Georgia, the issue of harmonization of our laws with the Convention was raised. In consideration of the mentioned fact was prepared a package of legislative changes, which aimed to bring our legislation into line with the Convention. It is worth noting the initiative taken by the Parliament of Georgia during the implementation of changes which refer to the changes that do not rise from any obligation further to ratify the Convention, although, when amending the Code, the Parliament explained such different approaches in consideration of the practice of other countries.

The circle of subjects of crimes considered by the given Chapter was defined in a new manner; qualifying circumstances were added, and the sanctions for certain crimes got aggravated.

The amendments made to the chapter on sexual freedom and inviolability refer to a new, fundamental change in the qualification of sexual offenses, which means forming a disposition in a new manner. Concepts such as "sex intercourse" and "sexual intercourse" were defined as any form of penetration of a sexual nature of the body of a person with any body part or object, committed with violence, under the threat of violence or by abusing a helpless condition of a person affected. With this explanation, the legislator expanded the circle of persons who might be the subject of the given crime, in addition, this change broke the diversity of opinions among scholars regarding the separation of the attempted and completed rape.

The amendments also affected the qualifying circumstances. They were regrouped and added by non - existent and qualifying circumstances such as: against a person under the custodianship, guardianship or surveillance of an offender, against a person with disabilities. Articles 140 and 141 of the Criminal Code were added by the qualifying circumstances.

Sexual crimes can only be committed through action. According to Professor Nana Todua "By inaction it is possible to participate in this crime, but not commit it because it is impossible for a person to commit violence or threat of violence or use the helplessness of a person by inaction." (Lekveishvili, M., Mamulashvili, G., \& 
Mailashvili, J., (2021)

Todua, 2019, p. 234). It has been suggested that rape can also be committed through inaction by a person who, through inaction, assists and helps the perpetrator in committing a crime and implements joint injustice (Gabaraevi, 2017 p. 259).

Sexual offenses can only be committed intentionally. The person is aware that he is using violence, the threat of violence or helplessness of a person is penetrating the body of a person of a sexual nature against the will of the victim and wants to complete it. Another corpus delicti is also deliberately committed.

The subject of sexual offenses is a responsible person who has reached the age of 14 , the subject of some corpora delicti may be an adult or a special perpetrator.

The research goal of the paper is to interpret the qualifying circumstances of crimes against sexual freedom and inviolability, to analyze the objective and subjective body of the action.

\section{Materials and Research Methodology}

What concerns the research methodology, the methods of analysis, synthesis and comparison - generalization were used while working on the article.

We used the method of synthesis in relation to the research topic to bring the knowledge gained through the analysis into one context and to get an overall image of the research subject.

Using a comparison method in relation to the research topic, we compared the norms governing sexual offenses in Georgia prior to the amendments to the Criminal Code. Common and distinctive features of the research object were identified by using the comparison method.

By using the generalization method, it is necessary to separate the norms from the relevant Articles of sexual crimes, which should be improved that will facilitate the process of correct assessment of the mentioned crimes.

\section{Main Part - Review of the amendments to the Criminal Code of Georgia 3.1. Article 137 of Criminal Code, Rape}

Rape is one of the serious crimes in terms of both, legal and moral evaluation. The type of criminal protection for crimes against sexual freedom and inviolability is the sexual freedom, sexual inviolability and normal moral and physical development of another. The object of criminal protection for rape is the sexual freedom and inviolability of another. Sexual freedom means that a person can choose or not choose a sexual partner. Sexual inviolability in case of raping an underage or a young person is an object of protection because his/her physical, mental, sexual and moral development is violated at such time, which can have a serious impact on the future growth and development of an underage or a young person. Prior to the amendments to the Criminal Code, there were differences in opinion among scientific circles with regard to the fact who might have been the victim of the rape, as well as the stages

88 Sciendo Journal of Legal Studies Volume 28 Issue 42/2021 
Ratification and Consequences of Sexual Offenses in the Criminal Code of Georgia

of the crime. After the amendments to the Criminal Code in 2018, this problem was removed and both, women and men can be affected, regardless of their attitude towards the offender, thus it may be the wife, ex-lover or wanton. The disposition of sexual offenses has significantly changed. Prior to the changes, "sexual intercourse" implied the existence of two opposite sexes and sexual acts against a woman's will. (Gamkrelidze, Ebralidze, Mamulashvili, Putkaradze, \& Bakanidze, 2008, p. 7). Following the amendments to the $\mathrm{CC}$, the concept of rape was formed in the following way: any form of penetration of a sexual nature of the body of a person with any body part or object, committed with violence, under the threat of violence or by abusing a helpless condition of a person affected. i.e. In addition to natural sexual intercourse, penetration of sexual nature into a man's or a woman's oral, anal or vaginal locations by using any body part such as a hand, an object (e.g. baseball bat) or something like a male sex organ (imitator) will be qualified as rape. It also does not matter if the person has an artificial penetrating location on the body after gender reassignment surgery (Gabaraevi, 2017, p. 68).

The methods of committing rape have not changed. These include rape committed with violence, under threat of violence or abusing a helpless condition of a person affected. During the violence, the offender uses physical force to overcome the victim's resistance. In cases where the abuser during voluntary sexual intercourse shows signs of sadism and causes bodily injuries to the victim to some degree, the offender's action must not be considered as rape but intentional bodily injury (Gotua, 1994, p. 12).

The threat of violence is also a method for overcoming the victim's resistance, which the offender uses to commit rape. Scientists define the threat as mental violence. While assessing the threat Professor Otar Gamkrelidze states the following: "Before using physical violence, the offender first uses mental violence and threat to overcome the victim's resistance" (Gamkrelidze, Ebralidze, Mamulashvili, Putkaradze, \& Bakanidze, 2008, p. 12). The threat of violence is directed against the affected person or the destruction of his/her close relative or property. Threats directed at the future cannot be considered rape. Professor Nana Todua states that "if the threat is directed as the action in the future will not be qualified as rape, even if the threat is real and well - grounded. Under Article 139 of CC it can be qualified as forcing penetration of a sexual nature into a person's body" (Lekveishvili, Mamulashvili, \& Todua, 2019 P. 236).

Rape by abusing a helpless condition of a person affected. When applying this method, the victim is in an unconscious condition due to severe intoxication, is ill or old and cannot resist the abuser. He cannot realize what is happening to him/her due to mental illness or mental retardation. To qualify it, it does not matter whether the offender put the victim in such a condition or he/she was in that condition for reasons beyond his/her control. Classically, the helpless condition is defined narrowly and it 
Mailashvili, J., (2021)

Ratification and Consequences of Sexual Offenses in the Criminal Code of Georgia

implies the absence of the victim's self-defense ability due to physical (e.g. paralyzed limbs, old age) or mental condition (mental disorder, young age, strong intoxication). Professor Tamar Gegelia supports the broad definition of a helpless condition in Georgian legal scientific literature. Professor Tamar Gegelia provides abuse of official powers, such as the relationship between a doctor and a patient, as an example of a broad interpretation of a helpless condition (Gegelia, Kelenjeridze \& Jishkariani, 2020, p. 41). As for the case when the victim, in addition to the age (under 14), was in a helpless condition, due to the victim's underage, the action must be qualified under Sub -Paragraph "C" of Section 4 of Article 137 of the Criminal Code. In addition, the investigation must determine the fact whether the abuser knew the age of the victim in advance. We will not have a rape crime if penetration of sexual nature took place with a false promise to the victim, for example, he will marry her in the future if she consents to any form of sexual penetration.

Rape belongs to the material element of the offense. In order to be recognized as completed, penetration of a sexual nature should take place into a person's body in any form by using a bodily part or an object. Professor Nana Todua believes that "from legal point of view, rape is considered completed from the beginning of penetration of a sexual nature, because a person's sexual freedem is already violated from that time. In order to recognize rape as completed, it is not necessary to get any other severe result other than that of penetration of a sexual nature" (Lekveishvili, Mamulashvili \& Todua, 2019, p. 238).

As for the stages of rape, first of all, it should be mentioned that Article 137, Part 1 of the Criminal Code is a category of serious crimes and the action is punishable even in the case of preparing a crime. In order to carry out the objective crime of rape, it is necessary that a person penetrate a victim's body by using violence, the threat of violence or the helpless condition of a person affected with a bodily part or an object. If the offender started violence or threat of violence and was unable to carry out penetration of sexual nature into the victim's body, then the action will be qualified as an attempted rape. And if a person makes the victim take sleeping pills in order to bring her into a helpless condition, and for some reason, he is unable to penetrate her body, his action will be qualified as preparation for rape. A person may voluntarily give up committing an offense for which he/she will not be liable for the rape unless his/her action includes signs of crime, such as beating, light or severe damage to health, force, etc.

Based on the subjective side, rape can only be committed by direct intention. A person is aware that he is doing penetration of a sexual nature against the victim's will by using violence, the threat of violence or the helpless condition of a person affected and wants to do so. The motive and purpose of the offense do not matter for the qualification. In most cases, rape is carried out by sexual motive, but the action 
Ratification and Consequences of Sexual Offenses in the Criminal Code of Georgia

may be committed by the motive of revenge. The offender sometimes aims to satisfy his sexual desire, or to make the victim pregnant, to break the hymen, and so on.

The perpetrator of rape is any person who has reached the age (14 years old) of criminal responsibility.

Now let's discuss the qualifying circumstances of Article 137 of the Criminal Code. Sub- Paragraph " $A$ " of Part 2 of the given Article refers to rape committed by taking advantage of an official position. The official position implies not only the status of public service but also of a private organization that makes it easier for the offender to commit a crime. This could be a relationship between a prison warden and an inmate, a company director, and a technical worker.

The next qualifying circumstance is rape which resulted in severe harm to the victim's health or other serious consequences. The subsequent result can be both intentional and negligent. Regarding the subsequent result for the qualification, Professor Nana Todua thinks that if the rape committed by the offender is followed by severe health damage due to negligence, then this action must be qualified under the above qualifying circumstance. And "if it is determined that the offender intentionally caused (both directly and indirectly) such an outcome, such action must be qualified as a combination of crimes under Article 137, Part 1 (unless there are other aggravating circumstances) and relevant part of Article 117 of the Criminal Code" (Lekveishvili, Mamulashvili \& Todua, 2019, p. 240). Therefore it can be said that the implementation of the objective offense of rape in the event of violence should be qualified as a combination of offenses if it was followed by severe health damage. Since rape and its attempt take place intentionally by the use of violence and the result is caused by negligence, then Article 137, Part 2, Sub-paragraph "A" of the Criminal Code shall be applied, which resulted in serious damage to health. Causing the given result implies negligence pursuant to Article 11 of CC. As for other serious consequences, they can be carried out both intentionally and negligently. For example, when the rape resulted in the careless transmission of AIDS to the victim, it would be the "other serious" consequence, and if the offender intentionally transmits AIDS to the victim during the rape, then there will be a combination of crimes under Article 137, Part 1 and Article 131, Part 2 of the Criminal Code.

Article 137, Part 3, Sub-paragraph " $A$ " of the Criminal Code, aggravating circumstance of rape committed repeatedly. Rape is considered repeated if a person convicted of rape continues to commit rape, provided that the person must not have his/ her conviction revoked or nullified for the offense previously committed. A person convicted of attempted rape or complicity has also been repeatedly convicted of rape.

Article 137, Part 3, Sub-paragraph "B" of the Criminal Code refers to committing rape by a person who had previously committed any crimes set forth in Articles 138- 
Mailashvili, J., (2021)

141 of the Criminal Code. This Subparagraph differs from Sub-paragraph "A" of Part 3 in that recurrence definitely implies the committing a crime by a person convicted of rape and Sub-paragraph "B" refers to a person who had previously committed a sexual offense under Articles 138 - 141 of the Criminal Code and the conviction has not expired or nullified and also criminal limitation period for the committed crime has not expired. If a person has not been previously convicted of any actions at the time of the rape, it will be qualified as a combination of offenses. Article 137, Part 3, Subparagraph " $\mathrm{C}$ " of the Criminal Code refers to committing rape by a group of persons. The group can act by prior agreement, without prior agreement or can be an organized group. Committing a group crime involves at least two perpetrators, i.e. co-perpetrators. In the case of group rape, it is not necessary that both perpetrators carry out penetration of a sexual nature in the body of a person affected. If one person was holding the victim's hands or legs while the other person was carrying out penetration of sexual nature into the victim's body, the actions of both persons would be qualified as group rape. Subjects of group rape may also be women. A person will not be considered as a co-perpetrator if he/she assists the perpetrator to complete rape, for example, he/she is as a "watchman" at the house in which the offender is carrying out penetration of a sexual nature into the body of a person affected. The action of the accomplice will be qualified by the relevant part of Articles 25, 137 of the Code.

The next aggravating circumstance is the rape committed knowingly by an offender against a minor, a person with a disability or a pregnant woman. Raping a pregnant woman knowingly, in addition to violating a woman's sexual freedom, poses a threat to the health of the embryo. No matter how many weeks pregnant, the main thing is for the offender to know that the victim is pregnant. If the abuser kills the victim after rape to cover up a crime, we will face a combination of crimes under Article 137, Part 3, Subparagraph "D" of the Code and Article 109, Part 1, Subparagraph "C" (for the purpose of covering up another crime) and Subparagraph "A" of Part 2 (with prior knowledge of a pregnant woman).

Rape of a minor. This Subparagraph refers to the case of rape of a person between the ages of 14 to 18 . In the case of raping a minor of that age, the object of criminal protection is sexual freedom and sexual inviolability as well as normal moral and physical development. The offender must know the exact age of the victim. If the offender did not know the age of the victim, he will become liable under Article 137, Part 1 of the Code. The investigation should determine the relationship between the victim and the offender, for example, a student and a teacher, a doctor and a patient, so that the offender does not try to avoid more serious responsibilities. When an adult rapes a minor under 16 and then continues to have voluntary sexual intercourse by the victim's consent, in this case, the action will be qualified as a combination of crimes under Article 137, Part 3, Subparagraph "B" and Article 140 of the Code. If 
Ratification and Consequences of Sexual Offenses in the Criminal Code of Georgia

the offender thought that he was raping a minor or a pregnant woman and in fact the victim was not found to be pregnant or a minor, the action will be qualified by Article 137, Part 1 of the Criminal Code.

A new aggravating circumstance was added to Article 137, Part 3 of the Criminal Code - Rape of a person with a disability. It should be noted that disability and helplessness conditions differ from each other. A person with a disability is characterized by physical, mental, intellectual, or sensory disorders, which are of solid nature. These disorders prevent a person with a disability to make full selfrealization with other individuals in equal conditions. It is noteworthy that not all helpless conditions are always a case of disability. A helpless condition can be a minor state, such as drunkness or sleeping. The same methods are applied when raping a person with a disability: violence, the threat of violence and the use of a helpless condition of a person affected. A question may be risen regarding how a case will be qualified when the offender knowingly has sexual intercourse with a person with a mental disorder by his/her "consent". In such a case, the "consent" of a person cannot be considered as an expression of free will. Since such a person with a disability is not able to take account of his/her action due to mental disorder and if the offender knows this circumstance, then this case must also be qualified as a rape of a person with a disability.

The next aggravating circumstance is Article 137, Part 3, Subparagraph "E" - Rape committed against a person under the custodianship, guardianship or surveillance of an offender. In this aggravating circumstance, the victim may be both an adult or a minor and he/she may be appointed by a guardian or a caregiver due to a health condition. The issues of assignment of guardianship and custody are given in the Civil Code of Georgia. As for supervision, a person may have an obligation to supervise an individual due to his/her job or under a contract of assignment. A babysitter or a caregiver may be assigned to supervise a person. For example, a caregiver raped a person he cares for by force or a babysitter raped a minor. If a babysitter is aware of the age of the victim, his/her action will be qualified under Article 137, Part 3, Subparagraph "D" of the Criminal Code, which will affect the appointment of punishment.

Rape committed against a person affected or any other person with extreme cruelty is considered as an aggravating circumstance under Article 137, Part 4, Subparagraph "A" of the Criminal Code. This circumstance is of an evaluative nature, which the court must assess finally and ascertain whether the crime was committed with extreme cruelty. Extreme cruelty has two criteria: subjective and objective. An objective criterion is manifested when the offender by his actions causes strong physical pain or moral, psychological suffer to the victim. A subjective factor refers to the fact that the offender is aware that he/she is causing strong physical or moral suffering to the victim and wants to do so. Motives of extreme 
Mailashvili, J., (2021)

Ratification and Consequences of Sexual Offenses in the Criminal Code of Georgia

cruelty can be different. It may be caused as a result of sadism or revenge or a complex of inferiority that developed due to impotence or sexual weakness, etc. Extreme cruelty is manifested before or at the time of the rape. But if extreme cruelty is manifested after rape, this action will be subject to separate legal assessment. Regarding the extreme cruelty against another person, Professor Zaur Tsulaia states the following: "Rape with extreme cruelty against "other person" requires its own interpretation, namely, it can be manifested in the same actions that take place against the victim and it is aimed at suppressing resistance to other persons and psychological influence on them" (Tsulaia, 2000, p. 195). Other persons may be both relatives of the victim and strangers. For example, when the offender undresses the victim in front of her father and rapes her by using physical force. Extreme cruelty against other persons may also occur when the victim consents to the penetration of sexual nature into her body instead of raping a girl of minor age.

Article 137, Part 4, Sub-paragraph "B" of the Criminal Code refers to rape which has caused the loss of life. This qualifying circumstance concerns the committed crime; i.e. a case of double charge where an intentional act resulted in the loss of life. The main act which resulted in the loss of life is considered a crime committed on purpose. But the result "loss of life of the victim" implies negligence. In this case, additional qualification is not required under Article 116 of the Code because the consequent result of rape aggravates and gives us a qualified corpus delicti. If the offender kills the victim of rape, the action will be qualified as a combination of crimes. Under the main corpus delicti of rape (Article 137, Part 1 of the Code) and Article 109 of the Code (for the purpose of easing the rape or covering up the crime) if the offender first kills and then has sexual intercourse with the corpse, then we will not have a case of rape, since there does not exist any sexual freedom or inviolability of the deceased woman. In this case, the action will be qualified as a combination of crimes under Article 108 of the Criminal Code (intentional murder) and Article 258 of the Criminal Code (showing disrespect for the deceased person).

Article 137, Part 4, Subparagraph "C" of the Criminal Code refers to rape committed knowingly against a person that has not reached 14 years of age. The object of violation of this crime is the sexual inviolability of a minor, his/ her moral and physical development. The offender must be aware of the age of the victim. If the offender has made a mistake in the victim's age due to various circumstances, then this action cannot be qualified under the mentioned subparagraph. Some scholars suggest that the rape of a minor under the age of 14 is equal to the rape of a person in a helpless condition. When stating this kind of position it is necessary that each case is ascertained individually since a person under 14 can be either 8 years or 13 years old. If the victim is aware of the nature of rape and he/she voluntarily consents to the offender to penetrate sexually into her/his body, the action will be qualified under Article 140 of the Code (penetration of sexual nature into the body of a person 
that has not reached the age of 16) and if penetration of a sexual nature took place in the body of an adolescent between the ages of 10 and 14, then it must be determined whether the adolescent was aware of the meaning, nature and expected outcome of sexual intercourse or penetration of a sexual nature. If, with the involvement of specialists, it is determined that the minor was not aware of the mentioned circumstances, then the victim will be considered to be a person in a helpless condition and the action will be qualified pursuant to Article 137, Part 4, Subparagraph "C" of the Criminal Code. Zurab Gotua suggested that sexual intercourse with a person under the age of 10 should in any case be qualified as rape committed against a person in a helpless condition. "If the offender is knowingly having a sexual intercourse with a girl who has not reached the age of 10 , his action should in any case be qualified as rape committed using a helpless condition of the victim, because a girl under the age of 10 is in no case aware of the social and moral meaning to the extent that her "consent" to sexual intercourse can be considered as an expression of her will" (Gotua, 1994, p. 31).

\subsection{Article 138 of the Criminal Code - Another action of a sexual nature}

As already mentioned, the amendments to Chapter 22 of the Criminal Code also applied to Article 138 of the Criminal Code. In the disposition of this Article as well as in the description of Article 137, the method of committing a crime such as violence, the threat of violence, or the use of a helpless condition of a victim remained unchanged. And the disposition of the action was formed as follows: Another action of a sexual nature, which does not contain elements of a crime under Article 137 of this Code, committed with violence, under the threat of violence or a helpless condition of a victim. In the disposition of the given norm, there is a reference to the components of the action of Article 137 and the boundary between these two components of the action should be committing another action different from rape. Logically a question arises: what is implied by another action? If rape involves the penetration of any form of sexual nature into a person's body using any bodily part or an object, during the qualification, under Article 138, the penetration of sexual nature into a person's body will be excluded. The object of criminal protection from the given crime is the sexual freedom or inviolability of a woman or a man. Normal moral and physical development or the health and life of an adolescent can be considered as an additional object. This action involves touching the victim's intimate areas with a hand or a sex organ or ejaculating on the victim's body by the offender forcibly, under threat of violence, or using a helpless condition of a person affected when there is no penetration of sexual nature into the victim's body. The offense is legally committed from the moment the offender begins another action of a sexual nature and it does not matter whether he/she actually completes such an action. The motive and purpose of committing a crime do not matter for the 
Mailashvili, J., (2021)

qualification of the action. More often in practice, the action is committed for a sexual motive and purpose. The subject of the crime is any responsible person who has reached the age of 14 . Both women and men can be affected. The crime is committed only with direct intention, the offender is aware that he is committing an act of a sexual nature using violence, the threat of violence or the helpless condition of a person affected. As for the qualifying circumstances of this Article, it is identical to the qualifying circumstances of rape and will not be reconsidered.

\subsection{Article 139 of Criminal Code - Coercion into the penetration of sexual nature into the body of a person, or into another action of a sexual nature}

The amendments made to the Criminal Code in 2018 also applied to this Article. Both the methods of coercion and aggravating circumstances have expanded. This norm protects the sexual freedom and inviolability of both women and men. The perpetrator of the offense is either a man or a woman who has reached the age of 14 . A victim may be a woman or a man, an adult, or a minor. An action is a coercion into penetration into a person's body of a sexual nature or another act of a sexual nature. The methods for committing a crime are the following: the threat of property damage, threat of disclosure of defamatory information, the threat of disclosure of information about personal life or such information that might substantially affect the person's right by using the victim's helpless condition, material, official and other dependence. This component of the action is formal, without consequences during which the offense is committed from the moment the victim is coerced and does not matter whether the offender manages to have a penetration of sexual nature into the victim's body or engage in another act of a sexual nature. From an objective point of view, coercion can be carried out by both action and inaction. For example, the threat of disclosing personal information or disclosing such information that could substantially damage the person's right might be carried out by action. And coercion by using the victim's helpless condition, material, official or other dependence can be done by both action and inaction. For example, the stepfather no longer provides material assistance to his stepchild, thus forcing her/him to consent to penetration of sexual nature into the body or another act of a sexual nature. Coercion in the present case cannot be understood as physical coercion and it must be understood as mental coercion. Physical coercion implies violence in its content and may give us the component of the action provided under Article 137 or Article 138 of the Code. Mental coercion is aimed at overcoming the victim's resistance and serves to obtain her/ his consent. "In the case of rape, the offender uses physical and mental violence to immediately seek sexual intercourse with the victim but in the case of this crime (here is implied coercion of a woman to have sexual intercourse) the offender tries to obtain the victim's consent to have sexual intercourse with him 
for which he uses the circumstance that the victim is dependent on him" (Makashvili, Matchavariani, Tsereteli \& Shavgulidze, p. $111-112$ ).

The threat of property damage can be used as one of the methods for coercion. This circumstance implies both damage and destruction. Threats can refer to all or part of the property. It should be noted that this property should be important for the victim. The interest of inviolability of the property must be such that the victim consents to the penetration of sexual nature into her/his body or another act of a sexual nature. If the perpetrator makes the threat reality and damages the victim's important property, the action will be qualified as a combination of crimes under Articles 139 and 187 of the Code.

The threat of disclosing defamatory information. This kind of circumstance exists not only against the victim but also against her/his family member. For example, disclosure of information about adultery; the defamatory information may be related to the threat of publicizing the victim's love affair. For example, the offender threatens a woman that if she does not consent to have an intimate relationship with him, he will give the secretly taken photos to her family members depicting her love affair that shows infidelity.

The threat of disclosing information about private life or such information which may substantially affect that person's right - This method of coercion is new in the disposition of the Article. This formulation refers to the disclosure of information about private life or personal data under Article 157 of the Code. If the offender threatens a woman after illegally obtaining photos about her private life that he will post the photos on social media unless she consents to an intimate relationship with him, this kind of threat gives us the completed corpus delicti; the threat of spreading other information may take place if it refers to the disclosure of any confidential information kept by the victim, such as the threat of disclosing personal information about health or information about the adoption of her child.

Using a helpless condition of a person affected - this kind of circumstance may be due to physical or mental condition if a person does not have the ability to resist physically or cannot realize the action taken by her/him due to mental disability. If the offender penetrates sexually into the victim's body using this circumstance, then we will have the component of the action of Article 137 of the Code. So, what is implied by coercion into the penetration of sexual nature into a person's body or another act of a sexual nature by use of a helpless condition of a person affected? We can respond to such cases when the offender knows that a person needs help because of her/ his helpless condition and forces her/ him to carry out the given action in return for providing that assistance. But this paper considers that the consent of a helpless person due to a mental condition should be understood as part of rape. Because the victim is deprived of the ability to express her/ his will and cannot realize and direct her/ his own action. In this helpless condition, we should 
Mailashvili, J., (2021)

imply coercion of a person who has no supporter and is physically unable to fully realize his/ her rights independently due to his/ her physical condition.

Coercion of a person dependent on the offender materially - This kind of situation occurs when the victim is materially provided by a person dependent on him, for example, the victim is provided with food, tuition fee, apartment rent, etc. The offender uses the situation and forces the victim to consent to him to have penetration of sexual nature into the body or another act of a sexual nature; this may also be done by inaction when the person no longer pays the rent for the victim and forces her/ him to consent to the action considered under the given Article.

The use of official position refers to such a situation where the Head by using the official position in a public or private institution, directly or indirectly coerces a subordinate person to consent the offender to the penetration of sexual nature into her body or to another act of a sexual nature, otherwise threatens her to cause problems or fire her. If the Head offers his subordinate promotion or sending abroad and persuades her to penetrate sexually into her body or carry out another act of a sexual nature, then we will not have a component of the given action, since the tempting offer is not coercion.

Use of another kind of dependence refers to a situation where a person with a certain profession or status uses her/his position in order to force his/her subordinate to consent to the penetration into her/his body of a sexual nature or another act of a sexual nature. As expressed in the scientific literature, "other kind of dependence should be considered as dependence between a teacher and a pupil, a lecturer and a student, an investigator and the accused, a coach and a sportsman, etc." (Lekveishvili, Mamulashvili \& Todua, 2019, p. 257).

The perpetrator of an offense is any person from the age of 14 . The offense is committed with direct intention, the motive may be different, mostly we have a sexual motive.

Before the amendments, the current version contained one aggravating circumstance, namely - the same action committed against a minor. I will no longer dedicate time to the qualifying circumstances of the current version because we have already reviewed them when discussing Article 137 of the Code.

\subsection{Article 140 of the Criminal Code - Penetration of sexual nature into the body of a person below 16 years of age}

The object of criminal protection of this norm is the sexual inviolability and moral, physical, and biological development of any person below 16 years of age. The penetration of sexual nature into the body of a person below 16 years of age takes place with the consent of the victim. A person will be considered guilty of committing such action from the age of 18. In addition, it is necessary for the offender to be aware of the victim's age. If the victim lies to the offender and tells 
$\mathrm{him} /$ her that she/he is beyond the age of 16 and the investigation determines that the offender misjudged the age of the victim, in this case, there should not be the offender's question of responsibility. The situation is different if a person knows that the victim is under 16 but tries to justify himself/ herself by not knowing the norm and he/she considered the penetration of a sexual nature with the victim's consent as legal and carried out the action due to the ignorance of the law. Such an "error" cannot become a ground for releasing the offender from liability. In court practice, we find cases when sexual intercourse is done with a person under 16 for the purpose of starting a family and in such cases, criminal prosecution begins against a potential husband. It is suggested that the public interest (identification/ punishment of an offender) and private interests should be taken into account and balanced in such cases. If the investigation reveals that there is a situation of starting a family, or a victim is already pregnant, then the relevant body should separate the accused person and terminate the investigation since the interest for punishing a person in such a case does not exceed the interest of starting a family and a pregnant woman's living with her breadwinner.

The subject of an offense for making penetration of sexual nature into the body of a person below the age of 16 is an adult who has reached the age of 18 . The amendments made to the Criminal Code expanded both the notion of rape and the circle of subjects. The objective content and subjective circle considered by Article 140 of the Code were also expanded. According to this norm, if a 17-year-old person commits an action considered under Article 140 of the Code, he/she will not be punished due to the absence of the subject of the crime. It is suggested that the legislator should make a change in the age of an offender (subject of the crime) and the age of the subject should be determined from the age of 16 years.

Among aggravating circumstances I would distinguish Article 140, Part 2, Subparagraph "B" of the Code, the same act committed against two or more persons. This act is committed with mutual intention against two or more persons by an adult who is having a penetration of sexual nature into the body of a person who has not reached the age of 16 , which does not imply an act committed independently, with other intention and separate actions of a long period interval during which we will get a combination of crimes. This will be taken into account by the court at the time of appointing the punishment. The motive and purpose of an offense are mostly of a sexual nature. There may be revenge as well. An offense is committed with direct intention. The offender is aware that he is carrying out penetration into the body of a person under 16 and wants to do so.

\subsection{Article 141 of the Criminal Code - Lewd Act}

This norm knowingly protects the normal moral development of a person who has not reached the age of 16. Professor Otar Gamkrelidze believes that the mentioned 
Mailashvili, J., (2021)

component during the lewd act protects not the normal moral development of adults but particular legal goodness is violated. This is the normal natural sexual growth development of the youth. (Gamkrelidze, Ebralidze, Mamulashvili, Putkaradze, \& Bakanidze, P.74) It is considered that the violation of normal natural sexual growth is part of the concept of sexual inviolability. Scientific literature suggests that lewd act is committed in two ways: physically and intellectually. The physical lewd act involves getting naked in front of a person under 16 or having sexual intercourse or another act of a sexual nature in his/ her presence, touching the genitals, or masturbating in front of a victim. If penetration of a sexual nature is carried out into the victim's body, then the action will be qualified under Article 140 of the Criminal Code. However, any other contact that does not involve penetration into the body of a person under 16, will be qualified pursuant to Article 141 of the Code. The intellectual lewd act involves showing a person under 16 literature of a sexual nature, conversations on topics about sex, and showing pornographic photographs or images depicting sexual scenes that are intended to satisfy sexual desires or aimed at arousing sexual aspiration. The above component of the act is an unintentional crime and it is completed from the moment of commencement of the given act and for the qualification of the act it does not matter whether the offender has achieved the set goal. The offense belongs to the category of intentional crimes.

\section{Conclusions}

Thus, the analysis of the paper in question can lead to the conclusion that the amendments made to the Criminal Code of Georgia on May 30, 2018, redefined the basic concepts of Chapter 22 of the Criminal Code (Crime against sexual freedom and inviolability), thus resolving a number of contradictions about different opinions among scientific circles with regard to the subject of rape as well as the stages of particular offenses considered by this Chapter such as legal and actual aspects of rape which presents an issue of sexual intercourse with regard to the separation of the attempted and completed rape. After the amendments made to the Criminal Code of Georgia, affected persons can be both women and men, adults and minors. The circle of special subjects and other qualifying circumstances were also improved in various components of the act.

It is considered that pursuant to Article 140 of the Criminal Code, determining the age of adulthood of an offender does not reflect the post amendment objective image, in particular, if a 17-year-old person carries out penetration of sexual nature into the body of a person who has not reached the age of 16, i.e. 15 years old and 10 months, he will not be punished. Given that the above action can be committed by both men and women, it is suggested that the legislature should determine the offender's age from the age of 16 years old. I also think that a similar approach should be applied to Article 141 (Lewd Act) of the Criminal Code and the offender's age shall be

100 Sciendo Journal of Legal Studies Volume 28 Issue 42/2021 
Mailashvili, J., (2021)

Ratification and Consequences of Sexual Offenses in the Criminal Code of Georgia

determined from the age of 16. This amendment will help to completely avoid the actions that are formed in Chapter 22 of the Criminal Code in a new manner. For example, the perpetrator of the components of Articles 137, 138, and 139 is a person who has reached the age of 14 . Of these three Articles, only Article 139, Part 1 includes a less serious crime and the subject of a crime is a 14-year-old person. Part 1 of Articles 140 and 141 of the Code is a category of serious crimes and the age of the subject is 18 years old.

\section{Acknowledgments}

The author thanks the anonymous reviewers and editor for their valuable contribution.

\section{Funding}

This research received no specific grant from any funding agency in the public, commercial, or not - for - profit sectors.

\section{Author Contributions}

The entire article was written by Jumber Mailashvilli.

\section{Disclosure Statement}

The author has not any competing financial, professional, or personal interests from other parties.

\section{References}

1. Council of Europe Convention on the "Prevention and Suppression of Violence against Women and Domestic Violence" 11.05.2011.

2. Gamkrelidze, O. Ebralidze, T. Mamulashvili, G. Putkaradze, E. Bakanidze, R., (2008). Commentary of Criminal Case Law: Crime against men, Tbilisi Publishing House "Meridiani".

3. Gotua, Z., (1994). Responsibility for Rape, Tbilisi, Publishing House "Sakartvelo".

4. Gabaraevi, I., (2017). Responsibility for committing rape by inaction. Faculty of Law of Tbilisi State University, Journal of Law \#2.

5. Gabaraevi, I., (2017). Rape as a sexual offense committed by violence. International peer-reviewed journal of Scientific - Research Institute, University of Europe, "Law and World" \#6 http://www.library.court.ge/upload/S\&M_N6_SUL4.pdf- January 15, 2021.

6. Gegelia, T. Kelenjeridze, I., Jishkariani, B., (2020). Sexual Offenses, Tbilisi, "World of Lawyers". http://www.library.court.ge/upload/http__icl.ug.edu.ge_publications_pub9.pdf January 15, 2021.

7. Lekveishvili, M., Mamulashvili, G., Todua, N., (2019). Private Part of Criminal Law, Book 1, Seventh edition. Publishing House "Meridiani". 


\section{sciendo}

Mailashvili, J., (2021)

Ratification and Consequences of Sexual Offenses in the Criminal Code of Georgia

8. Makashvili, V., Matchavariani, M., Tsereteli, T., Shavgulidze, T., (1980). Crime against a person. Publishing House "Metsniereba".

9. Parliament of Georgia, Law, 22/07/1999. Criminal Code.

10. Tsulaia, Z., (2000). Criminal Law, private part 1. Tbilisi. Publishing House "Intelekti". 